Portland State University

PDXScholar

1986

\title{
Morphological aspects of seedling establishment in four temperate region Phorandendron spp.
}

\author{
Beverlee M. Ruhland \\ Portland State University
}

Follow this and additional works at: https://pdxscholar.library.pdx.edu/open_access_etds

Part of the Biology Commons, and the Plant Sciences Commons

Let us know how access to this document benefits you.

\section{Recommended Citation}

Ruhland, Beverlee M., "Morphological aspects of seedling establishment in four temperate region Phorandendron spp." (1986). Dissertations and Theses. Paper 3702.

https://doi.org/10.15760/etd.5586

This Thesis is brought to you for free and open access. It has been accepted for inclusion in Dissertations and Theses by an authorized administrator of PDXScholar. Please contact us if we can make this document more accessible: pdxscholar@pdx.edu. 
AN ABSTRACT OF THE THESIS OF Beverlee M. Ruhland for the Master of Science in Biology presented December 18, 1986.

Title: Morphological Aspects of Seedling Establishment in Four Temperate Region Phoradendron spp.

APPROVED BY MEMBERS OF THE THESIS COMMITTEE:
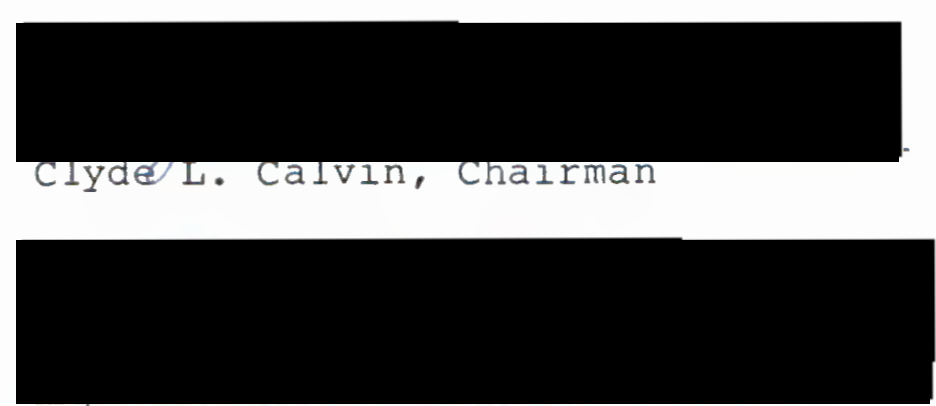

Robert 0. Tinnin

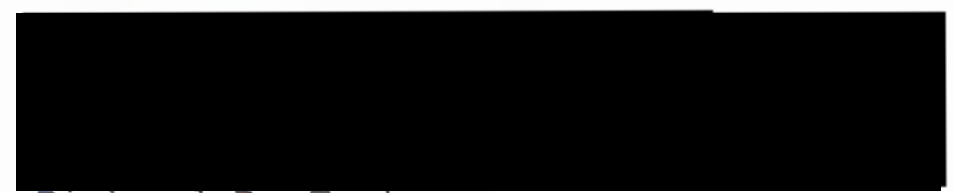

Richard D. Tocher

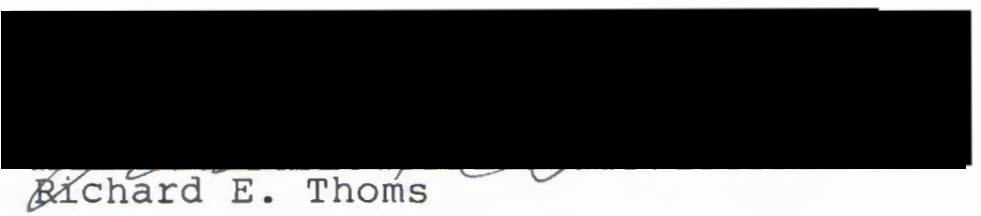

Four species of Phoradendron were examined for seed-

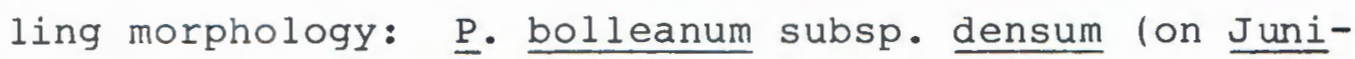
perus), $\underline{P}$. californicum (on Prosopis), $\underline{\text { P. juniperinum }}$ subsp. juniperinum (on Juniperus, P. villosum subsp. 
villosum (on Quercus). The main species used in the study was $\underline{P}$. juniperinum, using the other species for comparison. The initial shoot(s) of $\underline{P}$. juniperinum may develop from the epicotyl of the developing seedling, from adventitious buds which arise from a cushion of tissue, termed the haustorial cushion, formed beneath the holdfast, or from both positions. When shoots arise only from adventitious buds the original seedling remains attached in a lateral position, often persisting for a number of years, giving the false impression of an autoparasite establishing itself near the base of the plant. In $\underline{P}$. bolleanum and $\underline{P}$. villosum, initial shoots arise from the epicotyl although adventitious shoots may also develop, particularly in $\underline{P}$. bolleanum. In contrast, $\underline{P}$. californicum shoots are entirely adventitious in origin, and the initial seedling can frequently be seen near the center of the cluster of adventitious shoots. Cotyledons of all species in the study were found to be persistent and possess a distinctive tip probably resulting from the site of attachment to the endosperm. These distinctive, persistent cotyledons and other clearly identified morphological features, allow to readily distinguish between plumular and adventitious shoots. 
MORPHOLOGICAL ASPECTS OF SEEDLING ESTABLISHMENT

IN FOUR TEMPERATE REGION PHORANDENDRON SPP.

by

BEVERLEE M. RUHLAND

A thesis submitted in partial fulfillment of the requirements for the degree of

\author{
MASTER OF SCIENCE \\ in \\ BIOLOGY
}

Portland State University

1986 
TO THE OFFICE OF GRADUATE STUDIES AND RESEARCH:

The members of the committee approve the thesis of Beverlee M. Ruhland presented December 18, 1986 .

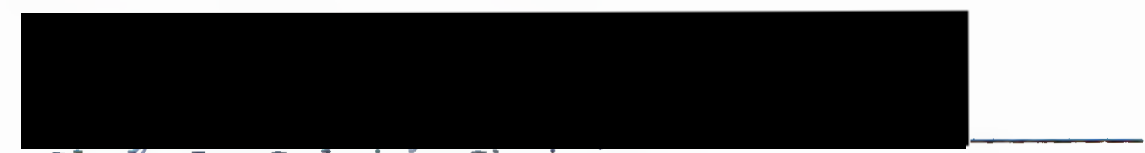

Clyde L. Calvin, Chairman

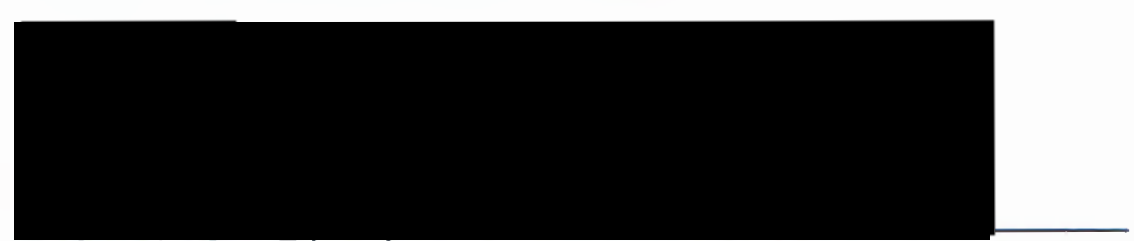

Robert O. Tinnin

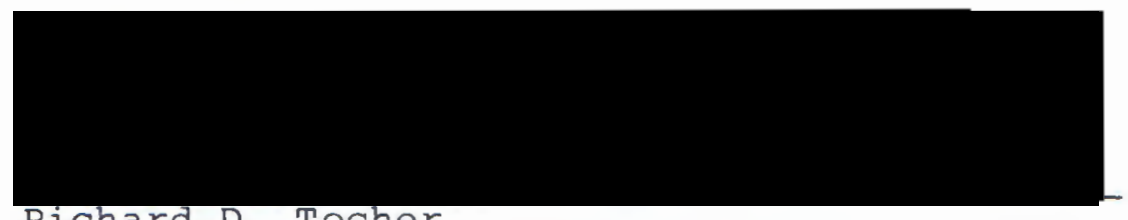

Richard D. Tocher

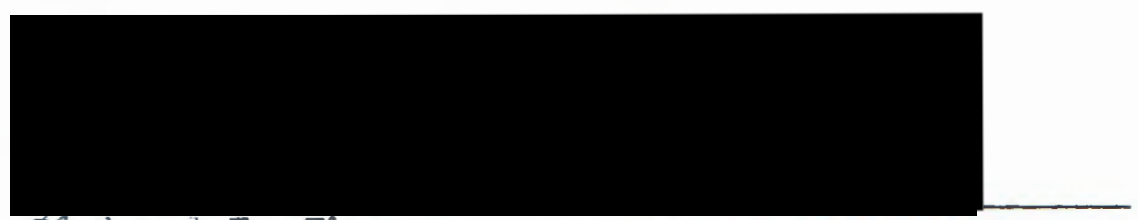

Richard E. Thoms

\section{APPROVED :}

Rlchard R. Petersen, Head, Blology Department

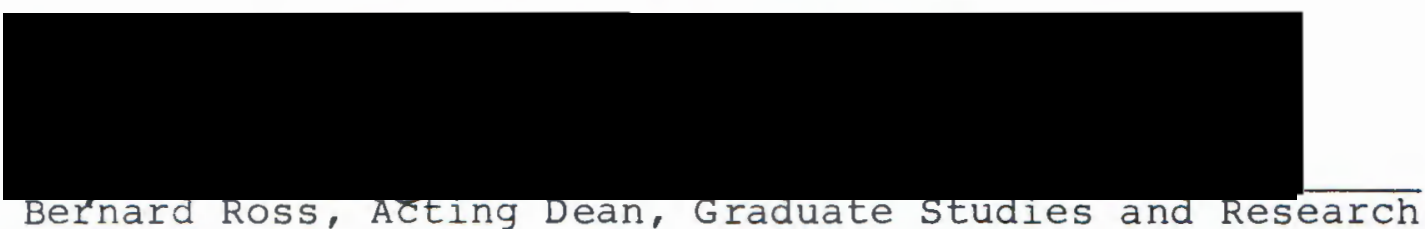




\section{ACKNOWLEDGEMENTS}

I want to extend my thanks to the members of my committee, Robert $O$. Tinnin and Richard D. Tocher and especially to clyde C. Calvin without whom this could not have been written.

My deep thanks goes to Delbert Wiens for collecting mistletoe for me with great alacrity when I greatly needed it. My gratitutde also goes to Richard Petersen who gave me time and support these last months. I am most endebted however to my husband and family who tolerated the absence of my attention during this process. 
TABLE OF CONTENTS

PAGE

ACKNOWLEDGMENTS....................... ii

LIST OF TABLES....................... v

LIST OF FIGURES........................ vi

INTRODUCTION........................... 1

MATERIAL AND METHODS...................... 9

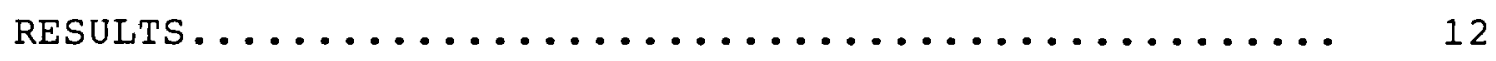

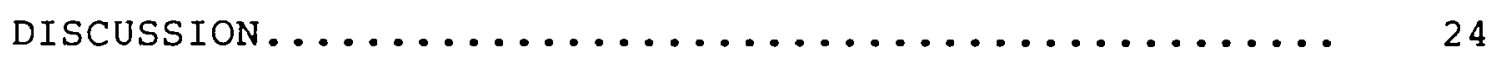

BIBLIOGRAPHY......................... 30 


\section{LIST OF TABLES}

TABLE

PAGE

I Collection Data for Phoradendron spp.

studied....................... 
1. P. juniperinum, germinating seed......... 13

2. P. juniperinum, seedling............. 13

3. P. juniperinum, seedling becomes erect..... 13

4. P. juniperinum, haustorial cushion with buds....................... 13

5. P. juniperinum, plumular shoot with curved hypocotyl....................

6. P. juniperinum, plumular shoot with

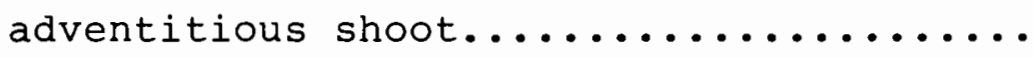

7. P. juniperinum, adventitious shoot with undeveloped seedling.............. 16

8. P. juniperinum, adventitious shoot with undeveloped seedling.............. 16

9. P. juniperinum, adventitious shoot with undeveloped seedling.............. 16

10. P. juniperinum, older infection with fused

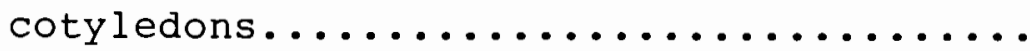

11. P. juniperinum, SEM photograph of cotyledon

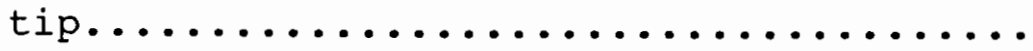


12. P. juniperinum, SEM photograph of cotyledon

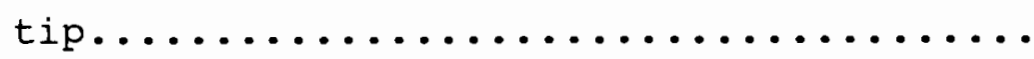

13. P. bolleanum, seedling............... 20

14. P. bolleanum, seedling with foliage leaves... 20

15. P. bolleanum, seedling with fused

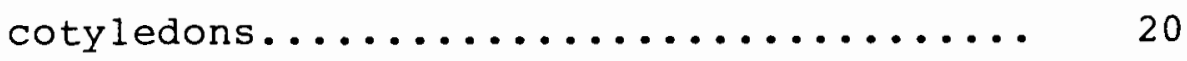

16. P. bolleanum, seedling with fused

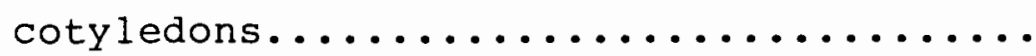

17. P. bolleanum, seedling with fused cotyledons..................... 20

18. P. bolleanum, older infection with

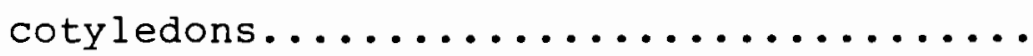

19. P. californicum, germinating seed with

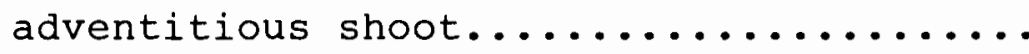

20 P. californicum, adventitious shoot cluster with original seedling remnants....... 22

21. P. villosum, mature plant with cotyledons... 


\section{INTRODUCTION}

The mistletoes are a heterogeneous group of parasitic flowering plants with a largely pantropic distribution (Barlow 1983). Historically they were placed in one large family, the Loranthaceae, but as they have been studied in more detail, evidence has indicated a greater separation. The mistletoes are currently placed in one of three families, the Loranthaceae, the Viscaceae, or the Eremolepidaceae (Kuijt 1969, Cronquist 1981). Although the largest number of genera are found in tropical clinates, a few genera, mainly in the Viscaceae, have extended their range into the North Temperate zone as far as the state of Oregon in the contiguous U.S. (Phoradendron) and into Canada and Alaska (Arceuthobium). The majority are shrubby, photosynthetic epipyhtes, although a few terrestrial forms are known (Fineran and Hocking 1983). All are characterized by some form of physiological bridge or interface, the haustorium, with the host vascular system. Most of the mistletoes tap only water and mineral nutrients from the host system, but a few, including Arceuthobium (Hull and Leonard 1964) and Tristerix (Mauseth, Montanegro, and Walckowiak 1984) have been shown to obtain photosynthetic product through this absorptive organ as well. 
The family Viscaceae is much smaller than the Loranthaceae and more extensively developed in the northern hemisphere. The family consists of seven genera. Of these, Viscum is endemic to the old World, and Phoradendron and Dendropthera are confined to the New World. The latter two have major centers of species richness in tropical South America, Central America, Mexico, and the Caribbean Islands (Barlow 1983). Kuijt (1969) notes that Phoradendron and Dendropthera are entirely sympatric and, despite the fact that viscacean genera are usually clearly defined groups, the main distinction between these two genera lies in the number of locules of the anther. Phoradendron, the major focus of this study, is considered the largest genus in the Viscaceae although the number of species is uncertain. Kuijt (1969) feels that taxonomists have greatly exaggerated the number of species, and Barlow (1983) cites a need for critical taxonomic revision. The genus is broadly divided into two categories based on the presence or absence of scale-like appendages, the cataphylls (Wiens 1964). Monographs of the genus include those by Trelease (1916) and wiens (1964) (acataphyllous species only). Wiens reports that the acataphyllous species are predominantly northern in distribution and all but one of the U.S. species are from this group. None occur farther south than Guatemala. Wiens describes the flowers as apetalous, unisexual, and so similar in gross 
morphology that the only difference from species to species lies in the number of segments per inflorescence. Since morphological reduction of floral characters is considerable, the features remaining on which to base distinctions between species are limited to such things as leaf size and shape, pubescence, and internode width and length. Using these criteria in his review of the four sections of acataphyllous species, wiens noted a progressive reductional trend of leaf area and internode length from one section to another.

A critical period for all plants, and particularly so for parasitic species, occurs during seed dispersal, germination, and seedling establishment (Lamont 1983). A suitable host must be found and the haustorial connection quickly established to insure survival. Adaptations seen among the viscacean genera, that facilitate effective seed dispersal in their unique ecological niche, include berries attractive to bird vectors (McKey 1973) and explosive fruits that travel up to $17 \mathrm{~m}$ to possibly encounter a prospective host (Hawksworth and Wiens 1972). Whatever the dispersal mechanism, the embryo and endosperm in nearly all species retain a layer of viscin derived from the mesocarp. This substance is sticky enough to adhere to a surface, yet slippery enough to allow sliding to a possibly advantageous position on the host (Kuijt 1969). Another remarkable property of viscin is its ability to withstand a number of 
dryings and wettings while retaining its stickiness but gradually losing its slippery properties (Paquet et al. 1986). The excision of the seed is proposed as the trigger for breaking predispersal dormancy. Upon attachment to the host surface, germination can be timed to insure optimal conditions for efficient growth (Lamont 1983, Sallé 1983). A chlorophyllous endosperm may assist in respiration and photosynthesis during this highly vulnerable period (Harris 1976). Germination occurs immediately unless unsuitable climatic conditions exist, sensed by the photosensitive apex of the embryo which usually protrudes beyond the seed (Lamont and Perry 1977). Most studies of tropisms in growing radicles show them to be largely geotropically neutral and negatively phototropic (Kuijt 1964, Scharpf 1970). In any event, when the radicle contacts the host surface, a disc-like holdfast forms, signaling the initial phase of seedling establishment. At this point the mistletoe penetrates the host epidermis with mechanical force (Scharpf and Parmeter 1962) and possibly enzymatic action (Jaramillo 1975). Entry through the host stomata has also been observed in a highly reduced loranthaceous mistletoe, Tristerix aphyllus (Mauseth et al. 1985). Initial penetration may be countered by host defensive measures such as barriers of cork (Jaramillo 1975), and exudates of sap (Cowles 1972,1977$)$. Once penetration is complete the 
endophyte grows and ramifies in the host tissue forming vascular contacts.

The successful establishment of seedlings is signaled by the development of aerial shoots. A great range of morphologies are seen among the mistletoe families at this time. Kuijt (1982b) has described seedling morphology in a number of New World genera of Loranthaceae and Eremolepidaceae, illustrating shoot origin and cotyledon morphology. It appears that in nearly all cases the initial shoot develops from the epicotylar pole of the seedling axis. Adventitious shoots are not reported to arise in the hypocotylar region although epicortical roots do develop from the enlarged base of this area in some species (Kuijt 1982a). Kuijt (1982b) reported considerable variation in cotyledon number, morphology and function. Two cotyledons are considered normal, but in Psittacanthus spp. the number varies from two in some species up to eleven or more in others. He uses a number of terms to describe observed variations in seedling morphology: phanerocotyly, cotyledons spreading in the usual manner; cryptocotyly, cotyledons remaining partially or totally embedded in the endosperm; gamocotyly, cotyledons fused along their margin; and schizocotyly, cotyledons forked. Kuijt makes the statement "All genera in the New World except Tristerix have free cotyledons which in virtually all cases spread and are photosynthetically active." He cites $\underline{\text { T. aphyllus }}$ 
as a special case representing the most highly evolved condition in the Loranthaceae. The cotyledons show both gamocotyly and cryptocotyly, possibly performing an absorptive function. This extreme condition necessitates shoot formation from the endophyte only, since the epicotyl never develops (Mauseth et al 1985).

The Viscaceae are considered to have relatively uniform seedlings (Kuijt 1982b) except the genus Arceuthobium. Due to their economic implications, Arceuthobium spp. are studied in detail and are considered the most advanced. Epicotylar growth is suppressed in favor of endophytic establishment (Kuijt 1969), somewhat like that described for $\underline{T}$. aphyllus. The cotyledons in this instance, however, are only rudimentary, and the shoot apex only slightly developed (Cohen 1963). Shoots arise adventitiously from the endophytic system and may not emerge until two or more years after initial infection (Hawksworth and Wiens 1972). Among the other viscacean genera it is generally accepted that most initial shoot growth is from the epicotylar pole of the seedling. Few descriptions of viscacean seedlings comparable to Kuijt's treatment of the New World Loranthaceae have been written since the early studies of Viscum and some Phoradendron spp. Tubeuf's classic work on the old World genus Viscum (1923) depicts cotyledons in photographs and drawings as phanerocotylous and two in number. Aerial shoots are shown primarily as arising from 
the epicotyl, but a few cases are noted in which adventitious shoots arise from the endophyte when the plumule is lost. York's (1909) study of Phoradendron flavescens describes cotyledons as occasionally remaining embedded in the endosperm for a year or more before emerging while the shoot grows up between their bases. Other studies by Cannon (1904) and Bray (1910) give only scanty details concerning seedling morphology. A more recent work on Phoradendron flavescens (Calvin 1966) includes a photograph of a seedling showing distinct cotyledons but they are not identified. Anatomical studies of the phoradendron embryo show the cotyledons to be more highly developed than in Arceuthobium and the shoot apex more clearly defined (compare Cohen 1963, Fig. 3 with Calvin 1966, Fig. 9). The degree of development in the seed, however, does not necessarily indicate the ultimate morphology or fate of the seedling after germination. Recognition of the cotyledons is one of the primary means to interpret shoot morphology (Eames 1961). Kuijt (1982b) points out that an insufficient data base exists on seedling structure. Major change from the usual sequence of seedling growth such as reduction or suppression of embryonal apical differentiation seems to be an evolutionary trend in parasitic flowering plants (Teryokhin and Nikiticheva 1982). Furthermore, an incomplete understanding of the origin of aerial shoots can lead to a misinterpretation of life cycle sequences 
important to physiological, developmental, and taxonomic determinations. Due to this lack of basic information a study was undertaken of four species of phoradendron. observations in the field indicate a greater variation exists among the species than has generally been reported. 


\section{MATERIAL AND METHODS}

The four species of Phoradenron selected for this study were: Phoradendron bolleanum subsp. densum (Torr) Wiens, Phoradendron californicum Nutt., phoradendron juniperinum Engelm. ex A. Gray subsp. juniperinum, Phoradendron villosum (Nutt.) subsp. villosum. These species were chosen because: (1) they were available for collections of fresh material, (2) their location on the northernmost limit of their ranges best illustrates ecological effects, and (3) they represent a trend of reduction cited by Wiens (1964).

Due to the nearness of the site and availability of seedlings for collection and observation $\underline{P}$. juniperinum received primary consideration, and the other species were used for comparison. All materials collected were brought to the laboratory and examined while fresh under a zeiss dissecting microscope. Some specimens were also preserved in formalin-propionic acid-alcohol for further study.

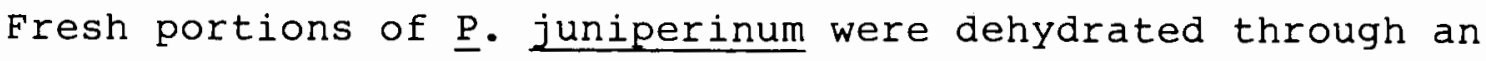
alcohol series and critical point dried according to the method described in O'Brien and McCully (1981) for examination of the cotyledon tips in the scanning electron microscope. Description of gross shoot morphology centered on: the presence or absence of the cotyledons and their 


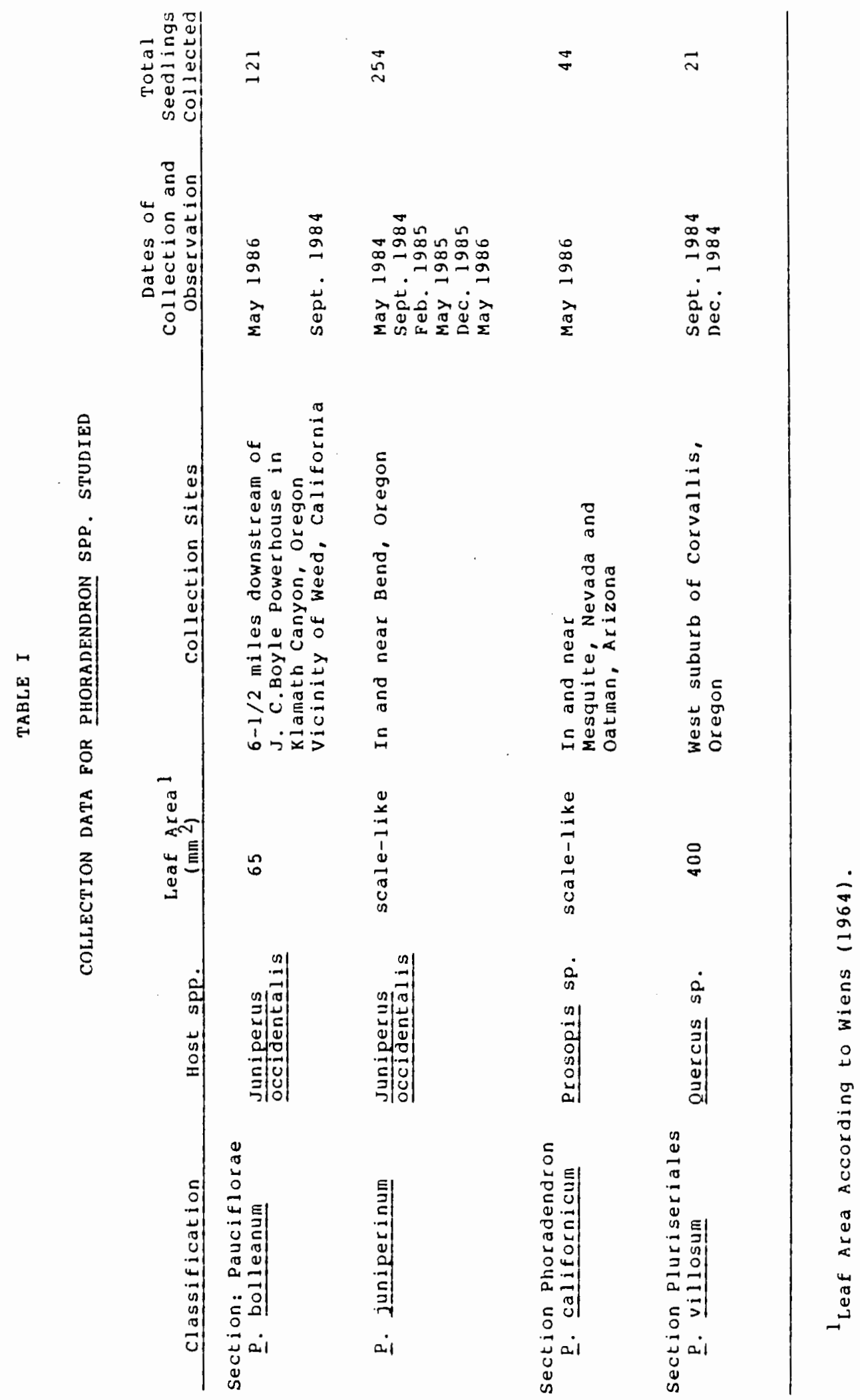


appearance; origin of aerial shoots, whether epicotylar or adventitious; the fate of the plumule, whether it grew or failed to develop. 


\section{RESULTS}

In the Bend, Oregon study area fruits of Phoradendron juniperinum reach maturity in the early winter. Several bird species (zilka 1973), feeding on mistletoe fruits, void seeds in nearby branches including those of the host species (Fig. 1). Once attached to host twigs germination begins. In $\underline{P}$. juniperinum, pictured in Figs. (1-10), and all other Phoradendron spp. examined in this study, the radicle is the first structure to emerge from the seed (Fig. 1). The specimen shown was collected in mid-May and reflects the slow but continuous growth of the green radicular axis. Eventually the radicle tip reaches a penetration site which is typically, but not always, beneath a scale leaf and forms a holdfast (Fig. 2). Throughout this stage the cotyledon tips remain embedded within the endosperm which is in turn covered by the sclerophyllous "seed" coat (Fig. 2). As development continues, the seedling becomes erect, shedding the remnants of the endosperm, and the plumule begins to extend (Fig. 3).

At this early stage of seedling growth striking variations become evident. In many seedlings an expanded region of tissue, here termed the haustorial cushion, develops beneath the holdfast raising it above the host surface (Fig. 4). Of 254 seedlings examined 52 percent developed this 


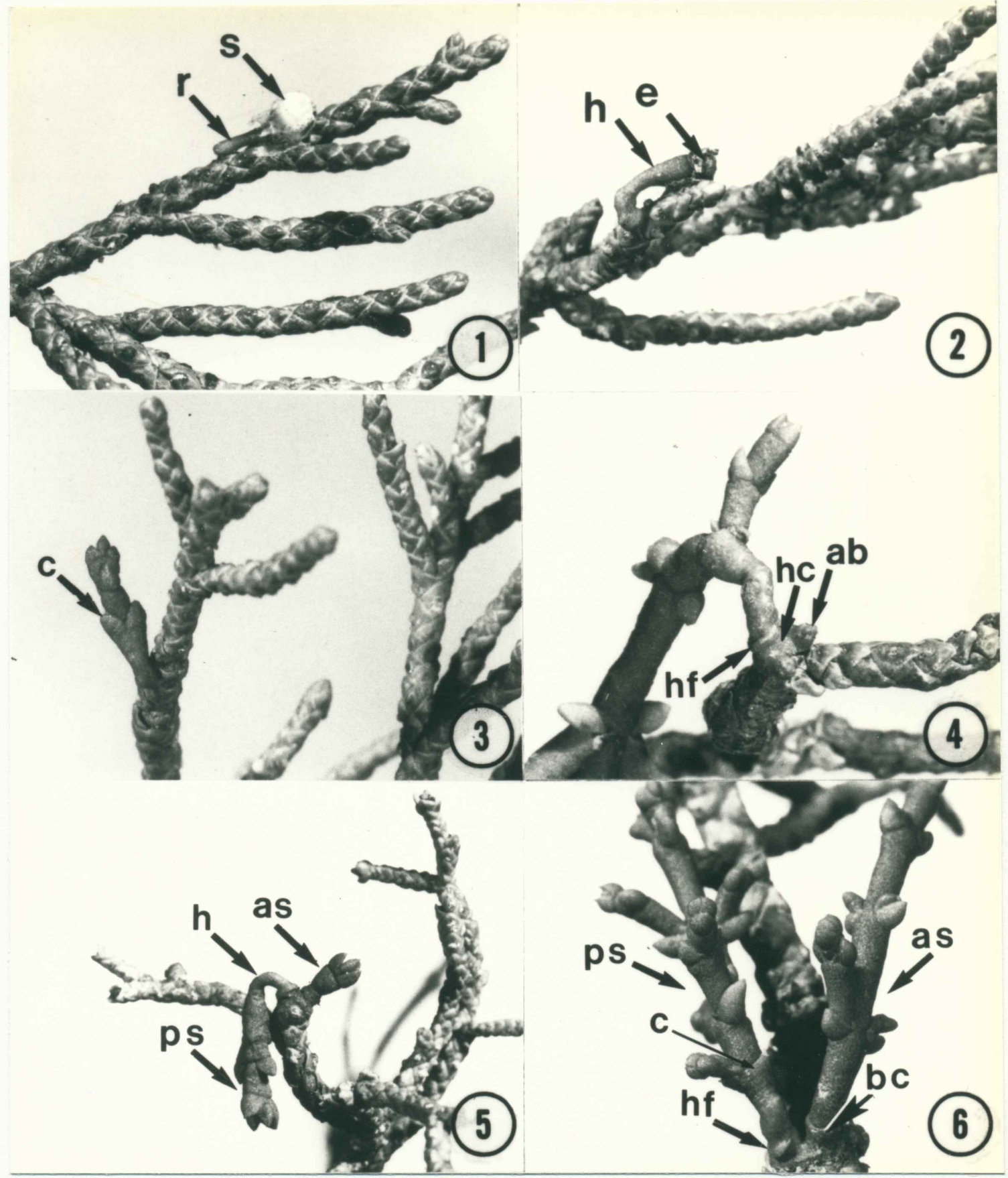

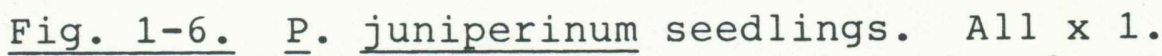

1. Seed(s) with extending radicle $(r) .2$. Attachment complete, endosperm (e) remaining. 3. Shoot with extending internodes. 4. Shoot with haustorial cushion (hc) and adventitious buds $(a b)$. 5. Shoot with curved hypocotyl (h). 6. Plumular shoot (ps) and adventitious shoot (as) showing distinguishing features. Basal cup (bc), cotyledon (c), holdfast (hf). 
cushion. Typically, two to four adventitious buds arise on the cushion (Fig. 4), but as many as eleven were observed. These buds may remain dormant for a time (Fig. 4) or initiate shoot growth almost as soon as they appear (Fig. 5). Seedlings which failed to form a cushion did not develop adventitious shoots at the initial infection site. However, adventitious shoots often form later directly from the endophytic system. The development of shoots from the endophytic system is a common phenomenon in some viscacean genera and has been observed by several workers (Bray 1910, Cannon 1901, Kuijt 1969, York 1909).

In approximately 20 percent of specimens studied adventitious shoots originating from a haustorial cushion equalled (Fig. 6) or surpassed plumular shoots in size by the time the latter had five extended internodes. Adventitious shoots can be identified by a basal, cup-like structure, presumably the lowermost leaf pair. Plumular shoots, on the other hand, can be distinguished by a visible holdfast and cotyledons (Fig. 6).

Adventitious shoots often appear more vigorous than shoots developing from the embryonic shoot apex. This vigor may be related to several factors. Frequently adventitious shoots have a darker green color than the plumular shoot, possibly reflecting greater photosynthetic capacity. A constriction--not seen in adventitious shoots--is often evident in the hypocotyl region 
immediately above the holdfast (Figs. 4, 5). Additionally, extreme curvature of the hypocotyl can occur in this region. These features may diminish the quality and quantity of the vascular connection. This constriction and/or curvature may also represent a weak point, since seedlings broken off in this region were observed in the field.

A particularly interesting feature observed in some $\underline{P}$. juniperinum seedlings is the complete absence of growth from the plumular apex. This phenomenon was noted in about 10 percent of the seedlings examined. In this event, growth of the adventitious shoots displaces the original seedling to a lateral position near the base of developing shoots (Figs. 7, 8, 9). The remnants of the initial seedling are persistent, and have been seen on infections in which developing adventitious shoots had ten or more extended internodes. When first observed these undeveloped "basal" seedlings were interpreted to be autoparasites, but as a broad range of developmental stages were studied the true sequence of events became evident.

P. juniperinum generally has two cotyledons (Fig. 3) although the number ranges from one to three. Usually the cotyledons are free and spreading, that is, phanerocotylous (Fig. 6), but some are partially or wholly fused along one edge. Sometimes the cotyledons are fused to such an extent that the demarcation between the individual cotyledons is difficult to discern (Fig. 10). The cotyledons display a 

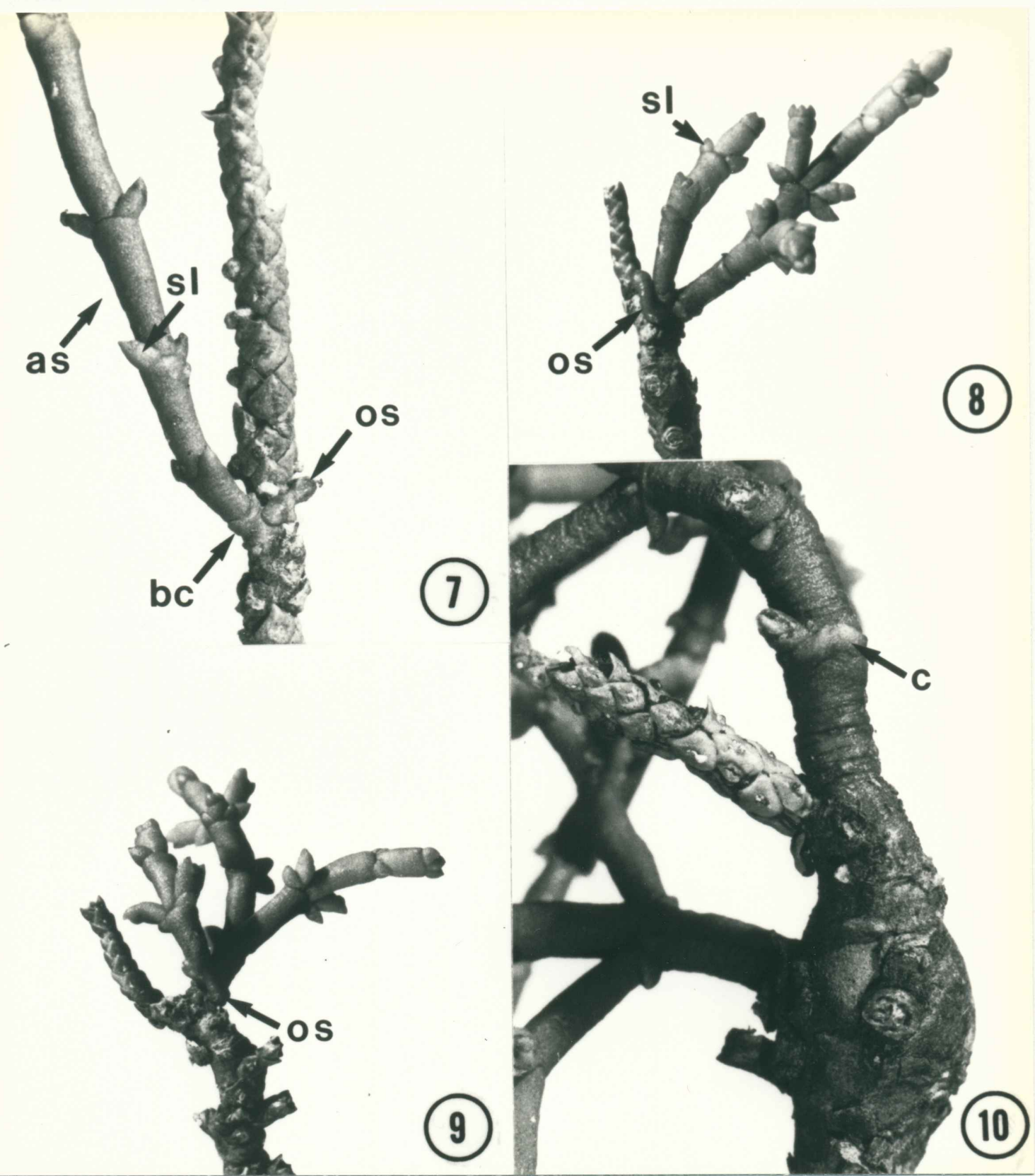

Fig. 7-9. Arested seedlings of $\underline{P}$. juniperinum with adventitious shoots. All $\times 1$.

7. Original seedling (os) is chlorotic. 8. Seedling appears green and viable. 9. Cotyledons can be seen but no plumule has emerged. Fig. 10. Older seedling showing persistent cotyledons (C) that are fused. Adventitious shoot (as), basal cup (bc), scale leaf (sl) . 
set of morphological characteristics that distinguishes them from subsequent leaf pairs. First, their extreme tips (approximately $1 \mathrm{~mm}$ ) are seen to be pointed and chlorotic upon removal of the endosperm. Later the points appear brown and withered. Viewed with the scanning electron microscope the minute, pointed tip is quite conspicuous (Fig. 11). Of interest are the many small trichome-like extensions protruding from this tip. Closer examination suggests that the extensions are of subepidermal origin (Fig. 12). Possibly, these extensions served a suctorial function in relation to removal of nutritional materials from the endosperm. In any event, these minute tips are nearly always present, and can be seen when cotyledons are examined closely (Fig. 6), although they are not always distinct at first glance. Second, the cotyledons join smoothly and without interruption with the hypocotyl region (Fig. 3), whereas the subsequent scale leaves show a definite line of demarcation at their junction with the stem (sl in Figs. 7, 8). When comparing the plumular shoot and the adventitious shoot in Figure 6 , the difference between cotyledons and scale leaves provides an important criterion for distinguishing between the two shoot types. Using the characteristics described, cotyledons make a reliable indicator of plumular shoots in the field. Although their shape is somewhat changed as the stem increases in size, 

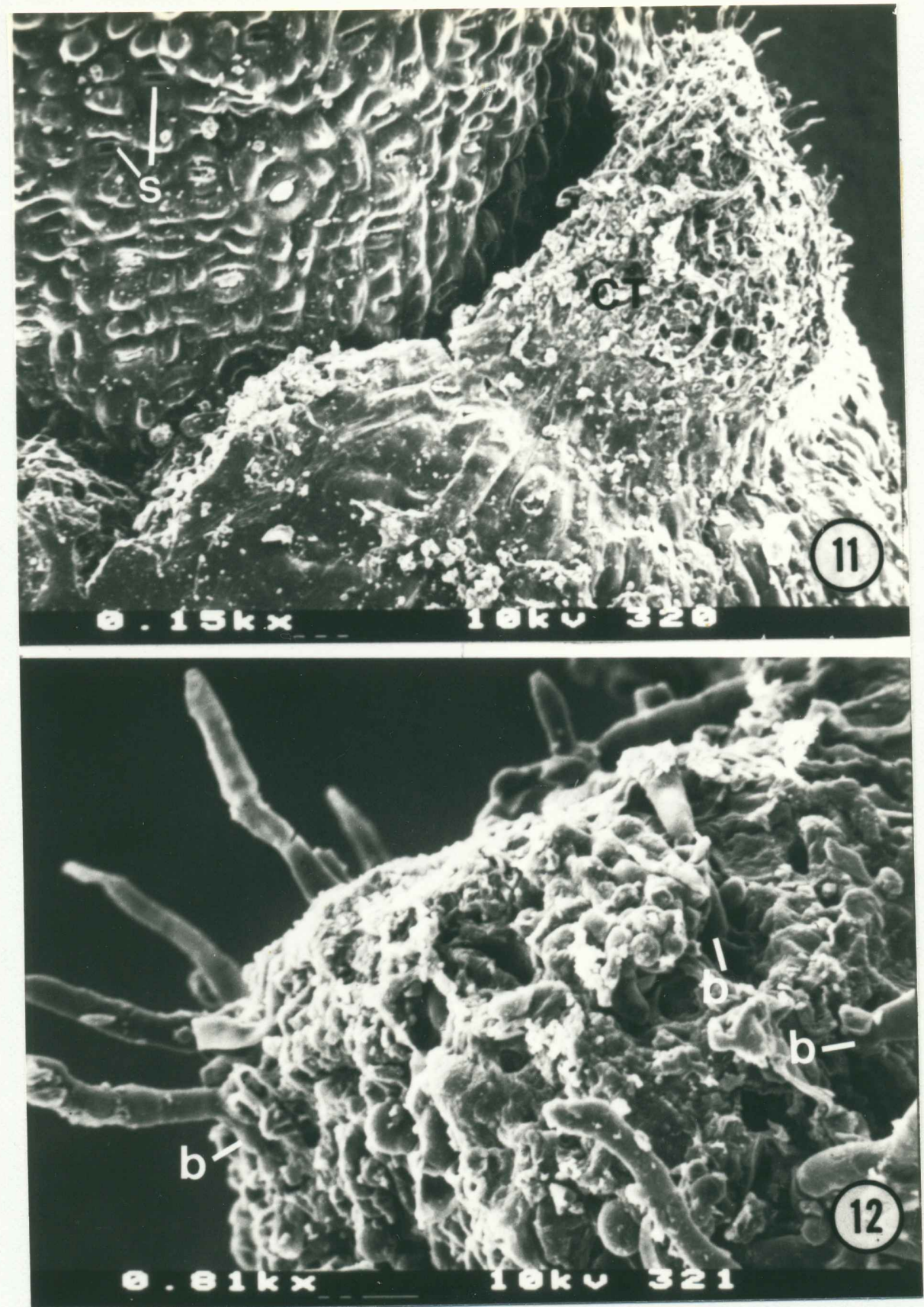

Fig. 11-12. Cotyledon tip of $\underline{\mathrm{P}}$. juniperinum.

11. Extreme end, appearing necrotic. 12.

Closer view, showing trichome-like extensions.

Base (b), cotyledon tip (CT), stomate (s). 
they can still be identified on specimens such as the one seen in Figure 10, which has over 20 extended internodes. Phoradendron bolleanum (Figs. 13-18) follows closely the sequence of events described for early seedling growth of $\underline{P}$. juniperinum. Following germination and holdfast formation, the seedling becomes erect (Fig. 13). A haustorial cushion may also form, but not as commonly as in J. juniperinum. Of 121 specimens examined, 37 percent had this structure. Generally one or two adventitious buds are initiated on the cushion, but 90 percent of these had not developed into shoots even after seven extended internodes were visible on the plumular shoot. It was noted, however, that all buds produced shoots in the six cases where the original seedling had been damaged by insect herbivory or mechanical injury. This species produced adventitious shoots primarily from the endophytic system, and large clusters of these shoots are found at varying distances from the initial infection site. In no case was original seedling growth arrested, as was illustrated for $\underline{P}$. juniperinum in Figures 7-9.

The cotyledons of $\underline{P}$. bolleanum, which are usually two or three in number, display the distinct morphological features described for $\underline{P}$. juniperinum (Fig. 14). Fusion of the cotyledons is common, occurring at their tips (Fig. 15), along their margins (Fig 16), or a combination of these (Fig. 17). In any event, the cotyledons do not 


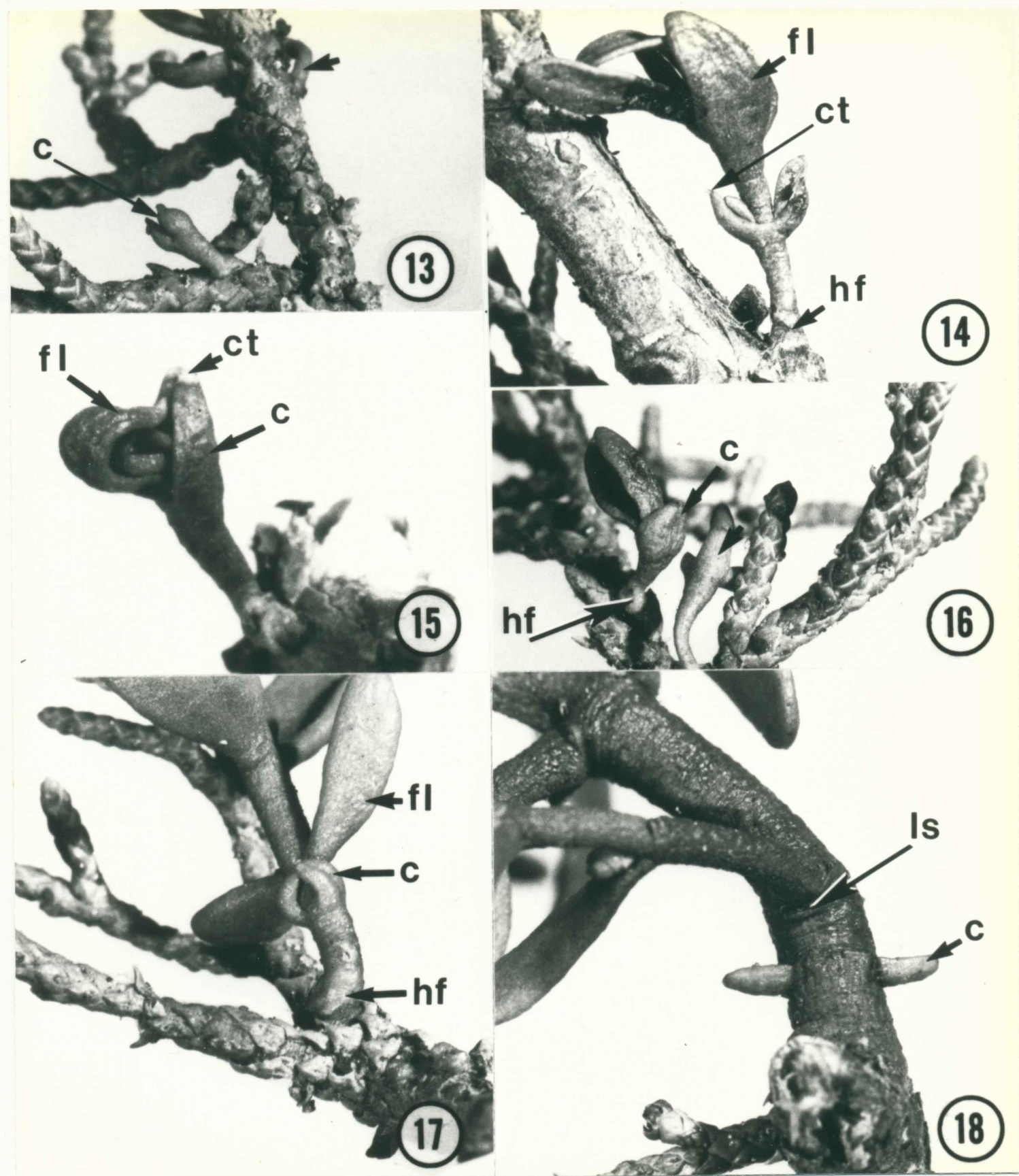

Fig. 13-18. P. bolleanum cotyledons. All $x 1$. 13. Endósperm shed. 14. Spread normally, tips (ct) visible. 15. Fused at tip, foliage leaves (fl) emerging. 16. Fused along one margin. 17. Three cotyledons, fused at tips and two fused at margins. 18 . older seedling with persistent cotyledons (C). Holdfast (hf), leaf scar (ls), additional seedlings indicated by unmarked arrow. 
appear to enlarge very much and remain smaller, although somewhat more succulent, than subsequent foliage leaves. With continued lateral expansion of the main stem, the cotyledons assume a position perpendicular to the stem axis, and they persist, even though foliage leaves above them are lost (Fig. 18). As in P. juniperinum, the cotyledons are reliable and even more obvious indicators for identifying plumular shoots.

seedling development in $\underline{P}$. californicum (Figs. 19-20) contrasts strikingly with that of $\underline{p}$. bolleanum. Upon germination the extending radicle, which is distinctly reddish in color, forms a holdfast from which the endophyte is established. Subsequently, an average of seven, but as many as twenty, adventitious buds arise from a thin, flattened haustorial cushion immediately beneath the holdfast (Fig. 19). When a large number of adventitious shoots are formed they may be present around the entire periphery of the cushion, resulting in shoots radiating outward all around the initial infection site (Fig. 20). Regardless of bud arrangement, the vast majority develop, resulting in infections having thick clusters of shoots. Adventitious shoots may also arise from the endophytic system, particularly when the initial infection site is at a node. of particular interest, the original seedling of $\underline{P}$. californicum was never seen to develop a plumular shoot in any of the approximately 50 infections for which the fate 

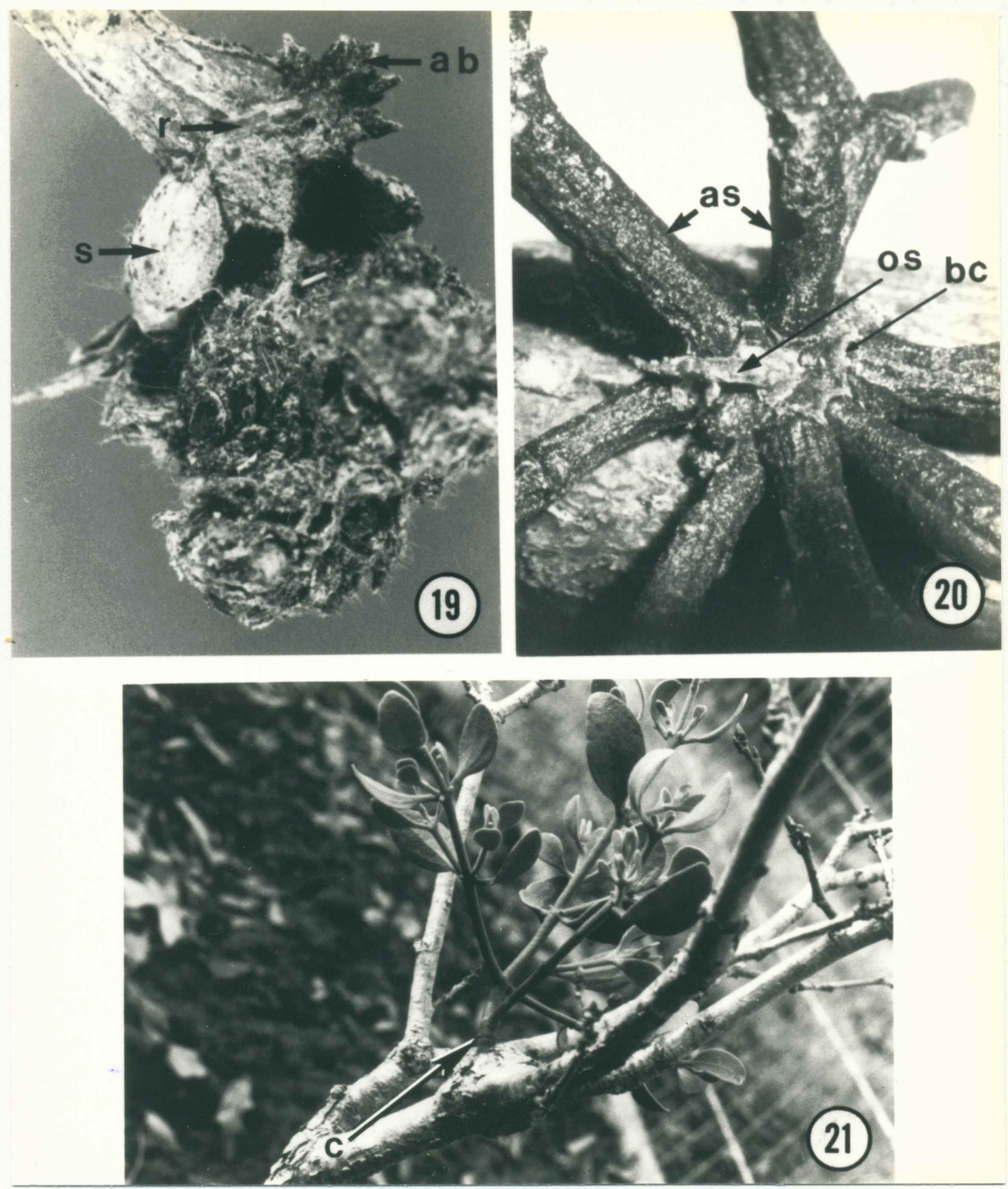

Fig. 19, 20. P. Californicum seedling. All x 1.5. 19. Germinating seed (s) with extended radicle ( $r$ ) and adventitious buds (ab). 20. Adventitious shoot (as) cluste with original seedling (os) at the base. Basal cup (bc).

$\frac{\text { Fig. } 21}{\mathrm{X}}$ i. . villosum, plumular shoot with cotyledons (c). 
of the original seedling could be determined. Instead, the original seedling remains as a necrotic-appearing, attenuated stub within the mass of adventitious shoots las in Fig. 20). Although not always readily visible, this structure clearly identifies the initial site of infection.

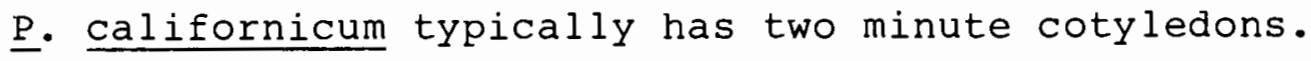
These cotyledons remain embedded in the endosperm--the cryptocotylar condition--and presumably play an important role in transfer of nutrients to the developing radicle. When seedlings with extending radicles were dissected from the endosperm, the upper portion encompassed by endosperm was seen to be deep green in color except for the tip, which may appear colorless.

The seedling establishment characteristics of $\underline{P}$. villosum conform closely to those "typical" of the genus as based on reports of other workers. Although seedlings of this species were difficult to locate in the field, those observed confirm that the plumular shoot develops as the main shoot. In none of the seven young seedlings studies was a haustorial cushion evident, and in none of the 21 total specimens examined did adventitious buds and/or shoots appear at the initial infection site. Presumably, adventitious shoots can develop from the endophytic system, but none were observed in the specimens examined. Rather, shoots of all ages, when examined closely, were seen to have two small, but persistent cotyledons (Fig. 21). 


\section{DISCUSSION}

The first aerial shoot of a phoradendron seedling has generally been regarded as being of plumular origin (Cannon 1901, Calvin 1966). In the present study the initial shoots of $\underline{\mathrm{P}}$. bolleanum and $\underline{\mathrm{P}}$. villosum were entirely plumular in origin, whereas those of $\underline{p}$. californicum were entirely adventitious. The initial shoots of $\underline{P}$. juniperinum can be either plumular in origin, or, less commonly, arise from adventitious buds. These contrasting patterns of shoot origin represent a greater diversity than has previously been recognized. The situation in $\underline{P}$. californicum is reminiscent of that seen in Arceuthobium spp. (Cohen 1963, Hawksworth and Wiens 1972) and in Tristerix (Loranthaceae) (Mauseth et al 1984) where the initial shoot and all succeeding shoots are adventitious. A major difference in $\underline{P}$. californicum, however, is that the numerous initial shoots are derived from an aerial portion of the seedling. In Arceuthobium and Tristerix, on the other hand, the initial shoots arise from the endophytic system, and do not appear until some time after penetration of the host and disappearance of the entire aerial portion of the seedling. In the case of Arceuthobium these shoots do not appear until at least two years after infection. 


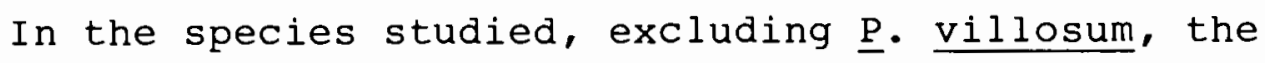
formation of a haustorial cushion is described. This cushion, which is of varying size, arises beneath the holdfast and is the site of adventitious bud origin in the developing seedling. In $\underline{P}$. juniperinum, which has the most pronounced cushion, development of the structure may markedly raise the holdfast above the host surface. Although a region comparable to the haustorial cushion has not been described by other workers, York (1909) does note that in $\underline{P}$. flavescens "the aerial shoots which are first formed usually arise from buds, which develop on the attachment disc ...." In the present study adventitious buds were never seen to arise on the holdfast (attachment disc). In $\underline{\mathrm{P}}$. californicum the cushion is much less obvious than in $\underline{P}$. juniperinum, and it may be that the species studied by York was of this type and the cushion was more easily overlooked.

The cotyledons of the Phoradendron species studied vary in both number and morphology. Most seedlings of $\underline{p}$. juniperinum have two cotyledons, but a few seedlings have either one or three. In $\underline{P}$. bolleanum either two or three cotyledons were observed, whereas in $\underline{P}$. villosum all plants observed had two cotyledons. Little can be said about cotyledon number in $\underline{\mathrm{P}}$. californicum because the cotyledons are minute and largely retained within the endosperm. The cotyledons of the species studied vary strikingly in size, 
with those of $\underline{P}$. bolleanum being the largest and most succulent in appearance. The cotyledons of $\underline{\mathrm{P}}$. juniperinum and P. villosum are intermediate in size and, as mentioned above, those of $\underline{p}$. californicum are minute. Fusion of cotyledons was common, particularly in $\underline{P}$. bolleanum. Previous workers have paid scant attention to the cotyledons, and their observations seem to conflict. Bray (1910), for example, states that in $\underline{P}$. flavescens the cotyledons become erect and "...slowly expand as the first pair of green leaves." York (1909), on the other hand, states that the cotyledons either wither or become slightly enlarged but never were observed to form foliage leaves. Observations on cotyledon development in the species utilized in the present study tend to parallel those of York (1909). Of interest, it was noted that the cotyledons were persistent and remained despite loss of subsequent leaves. Persistent cotyledons are considered unusual, and sporne (1974) cites only two cases, both in the family Gesneriaceae. Wiens (1964) recognizes four sections within the acataphyllous species of Phoradendron, and comments that "a progressivte reductional trend occurred from one section to another ... The Calyculatae possess the largest leaves, these exceeding those of the Pluriseriales. The Pauciflorae have still smaller leaves, some being reduced to scales. The section Phoradendron, including the single

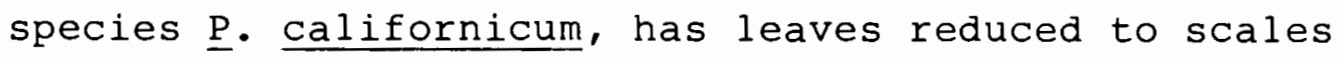


also." The present study examined species with a range of mean leaf sizes and belonging to three of the four sections identified by Wiens (Table 1). Evidence from the present study reveals that the progressive reductional trend characterizing foliage leaves has not extended to the cotyledons. $\underline{P}$. bolleanum has cotyledons that are larger than those of the closely related $\underline{P}$. juniperinum, and also the other species examined. Further, Calvin's (1966) illustration of $\underline{P}$. flavescens (mean leaf area $929 \mathrm{~mm}^{2}$ ) indicates that the cotyledons of this species are no larger than those of $\underline{P}$. juniperinum.

In Phoradendron increasing production of adventitious shoots is also considered to be an advanced trait (Kuijt 1969 ) and does correspond to decreased leaf size in the species examined. Arceuthobium, universally regarded as the most advanced viscacean genus, produces aerial shoots only adventitiously, and only from the endophytic system (Hawksworth and Wiens 1972, Kuijt 1969). The observations concerning seedling origin in $\underline{P}$. juniperinum and $\underline{P}$. californicum suggest transitional stages towards the evolutionarily advanced state characterizing Arceuthobium. Adaptations of this nature can be considered environmentally adaptive as well, allowing the parasite to successfully parasitize host species in increasingly harsher climates. Teryokhin and Nikiticheva (1982) describe four methods by which "the sporophyte of a flowering plant turns to 
parasitism." The evolutionary modificaiton seen in the Phoradendron species examined conform to the "orobanchoid form" which is characterized by a morphogenetically active radicular pole of the embryo which produces the nutritional contact with the host (the haustorium) and an increasingly reduced "embryo proper" (the plumule). This identical pattern is repeated in the tendencies seen in $\underline{P}$. juniperinum, where the plumule may not continue to develop after endophytic establishment, and in $\underline{\mathrm{P}}$. californicum, where plumular growth is almost totally suppressed.

The observations made in this study have relevance in other areas of botany. To illustrate, in a recent publication concerning mistletoe water use, schulze and Ehleringer (1984) describe the early growth of $\underline{P}$. californicum. It is stated: "In the first year, a single $1-t o-2 \mathrm{~cm}-10 n g$ sprout was formed, the seed coat was still visible, and there was no inflation on the host branch. In the second year, an inflation on the host branch was visible and the sprout showed initial secondary branching." Indications are, however, that this could not have been the sequence of events since all aerial shoots examined in the present study were adventitious in origin and the plumule itself failed to grow. This apparent misinterpretation could possibly have some bearing on the results reported. An accurate understanding of seedling morphology is required to interpret 
life cycles, thus definitive information of this aspect is valuable.

The results of this study presents a number of areas for future investigation. Obviously the seedling morphology of a broader range of species in the genus Phoradendron, including cataphyllous members, needs description. Other interesting aspects for further study include 1) an anatomical, cytological, and histochemical study of shoot apex suppression; 2) physiological studies related to adventitious bud formation; and, 3) an in-depth study of cotyledon structure and morphology. All of these investigations would clearly provide pertinent data important to a fuller understanding of the mistletoes. 


\section{BIBLIOGRAPHY}

Barlow, B. A. 1983. Biogeography of Loranthaceae and Viscaceae. Chapt. 2 In The Biology of Mistletoes. M. Calder and P. Bernhardt (eds.). Academic Press, New York.

Bray, w. 1910. The Mistletoes Pest in the Southwest. Bul. 166 Bureau of Plant Indusry. USDA 39 pp.

Calvin, C. L. 1966. Anatomy of mistletoe grown in culture. Bot. Gaz. $127(4): 171-183$.

Cannon, W. A. 1901. The anatomy of Phoradendron Villosum. Nutt. Torrey Bot. Club Bull. 28:374-390.

1904. Observations on the germination of Phoradendron villosum and $\underline{P}$. Californicum. Ibid. $31: 435-443$.

Cohen, I. I. 1963. Studies on the ontogeny of the dwarf mistletoes, Arceuthobium. I. Embryogeny and histogenesis. Amer. Jour. Bot. 50:409-417.

Cowles, R. B. 1972. Mesquite and Mistletoe. Pacific Discovery $25(3): 19-24$.

- 1977. Desert Journal. A naturalist reflects on arid California. Univ. California Press, Berkeley and Los Angeles.

Cronquist, A. 1981. An Integrated System of Classification of Flowering Plants. Columbia University Press, New York.

Eames, A. J. 1961. Morphology of the Angiosperms. McGraw-Hill Book Company, Inc., New York.

Fineran, B. A., and P. J. Hocking. 1983. Features of Parasitism, Morphology and Haustorial Anatomy in Loranthecean Root Parasites. Chapt. 12 In Biology of Mistletoes, M. Calder and P. Bernhardt (eds.). Academic Press, New York.

Harris, C. S. 1976. Germination and anatomy studies of Phoradendron serotinum. (Abstr). Virginia J. Sci. $27(2): 56$. 
Hawksworth, F. G., and D. Wiens. 1972. Biology and Classifications of Dwarf Mistletoes (Arceuthobium). Agriculture Handbook No. 401, U.S.D.A.

Hull, R. J., and O. A. Leonard. 1964. Physiological aspects of parasitism in Mistletoes Arceuthobium and Phoradendron. I. Carbohydrate Nutrition of mistletoe. Plant Physiol. 39:996-1007.

Jaramillo, A. 1975. Susceptibility of three conifer species to infection by Arceuthobium camoylopodum. Botan. Soc. Amer. Abstracts of papers presented at annual meeting, Oregon State University, Corvallis, August 17-22:44.

Kuijt. J. 1964. Critical observations on the parasitism of New World mistletoes. Can. J. Bot. 42:1243-1278 (+9 plates).

- 1969. In the Biology of Parasitic Flowering Plants. University of California Press, Berkeley and Los Angeles.

- 1982a. Epicortical roots and vegetative reproduction in Loranthaceae (s.s.) of the New World. Brit. iol. Pflangen 56:307-316.

- 1982b. Seedling morphology and its systematic significance in Loranthaeceae of the New World, with supplementary comments on Eremolepidaceae. Bot. Jahrb. Syst. 1033:305-342.

Lamont, Byron. 1983. Germination of mistletoes. Chapt.' 8 In The Biology of Mistletoes. Academic Press, New York.

Lamont, B., and M. Perry. 1977. The effects of light, osmotic potential and atmospheric gases on germination of the mistletoe, Amgema preissii. Ann. Bot. $41: 203-209$.

Mauseth, J. D., Montenegro, G., and Walckowiak, A. M. 1984. Studies of the holoparasite Tristerix aphyllus (Loranthaceae) infecting Trichocerecus chilensis (Cactaceae). Can. J. Bot. 62:847-857.

- 1985. Host infection and flower formation by the parasite Tristerix aphyllus (Loranthaceae). Can. J.

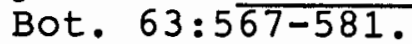

McKey, D. 1973. In Co-evolution of Animals and Plants. I. E. Gilbert and P. A. Peven (eds.), pp. 159-191. University of Texas Press, Austin. 
O'Brien, T. P., and M. E. MCCully. 1981. In The study of Principles and Selected Methods. Termarcarcarphi PTY, Ltd., Melbourne, Australia.

Paquet, P. J., Donald M. Knutson, Robert $O$. Tinnin, and Richard D. Tocher. 1986. Characteristics of viscin from the seeds of dwarf mistletoe. Bot. Gaz. $147(2): 156-158$.

Sallé, G. 1983. Germination and establishment of Viscum album L. Chapt. 9 In The Biology of Mistletoes, Academic Press, New York.

Scharpf, R. F. 1970. Seed viability, germination, and radicle growth of dwarf mistletoe in California. USDA Forest Service Res. PAP. PSW-59. $18 \mathrm{pp}$.

Scharpf, R. F., and J. R. Parmeter, 1962. The collection, storage, and germination of seeds of a dwarf mistletoe. Jour. Forestry 60:551-551.

Schulze, E. D., and J. R. Ehleringer. 1984. The effect of nitrogen supply on growth and water-use efficiency of xylem-tapping mistletoes. Planta 162:268-275.

Sporne, K. R. 1974. The Morphology of Angiosperms. St. Martin's Press, New York.

Teryokhin, E. S., and Z. I. Nikiticheva. 1982. Biology and Evolution of embryo and Endosperm in parasitic flowering plants. Phytomorphology 32(4):335-339.

Trelease, w. 1916. The genus phordendron: A monographic revision. University of Illinois Press, Urbana.

Tubeuf, K. 1923. Monographic Der Mistel R. Oldenbourg Verlag (Munchen und Berling).

Wiens, Delbert. 1964. Revision of the acataphyllous species of Phoradendron. Brittonia 16:11-54.

York, H. 1909. The anatomy and some of the biological aspects of the "American mistletoe," Phoradendron flavescens (Pursh) Nutt. Bulletin of the University of Texas 20, Sci. Ser. 13. 31. pp.

Zilka, P. J. 1973. Possible avian influences in the distribution of Dwarf Mistletoe. MS Thesis, Portland State University, Portland, Oregon. 